\title{
Examination of soils under grasslands in the territory of Kosjeric municipality
}

Snežana Anđelković*, Snežana Babić, Tanja Vasić, Jasmina Milenković, Jordan Marković, Mladen Prijović, Đorđe Lazarević

Institute for Forage Crops, 37251 Kruševac, Serbia

*Correspondiing author: Snežana Anđelković, snezana.andjelkovic@ikbks.com

\begin{abstract}
For successful plant production, optimum conditions for microbiological processes need to be ensured, since micro-organisms play a vital role in maintaining fertility of the soil. They respond quickly to changes in the soil ecosystem, so they represent good indicators of soil health. In order to improve plant production and proper soil use, we tested the soil quality of natural and indigenous grasslands of the Municipality of Kosjerić. Eleven samples from sown and nineteen soil samples from natural grasslands were analyzed, with chemical properties and total number of microorganisms determined. The majority of soil samples are of acidic chemical reactions, with medium humus and nitrogen content, low phosphorus content and sufficient amounts of potassium. The total number of microorganisms ranged from 5.778 to 6.431 ( $\log$ of the number) per gram of absolutely dry soil.
\end{abstract}

Keywords: soil, grasslands, microorganisms

\section{INTRODUCTION}

Grassland vegetation in the Republic of Serbia occupies about 1.5 million hectares or $27 \%$ of the total agricultural area (Simić et al., 2015). The largest areas under grasslands are in the hilly-mountainous area, with a percentage share in the total utilized agricultural land under meadows and pastures in the region of Sumadija and Western Serbia with 91.4\%, where meadows occupy 47.7\%, and pastures $43.7 \%$ (Arsić and Jovanović, 2013). Grasslands represent the most important and sometimes the only source of animal feed on the farms that have been established on these terrains. In addition, they are also important from the aspect of environment preservation, represent the habitat of many plant and animal species, the source of medicinal substances used in pharmacy, and they prevent soil erosion, etc. (Babić et al., 2016). In the largest part of the Kosjerić Municipality, natural grasslands are exposed to 
negative effects from two different directions. The first is the extensive use or even complete absence of utilization of grasslands, which leads to degradation of grasslands and reduction of biodiversity and to reducing the percentage participation of beneficial species. The second direction comes from the areas of intensive use of natural grasslands reflected in intensive fertilization and cutting. This approach, also, has harmful effects on the plant communities and is reflected in the directed change of floristic composition, pollution of the soil and watercourses.

Depending on the way and the intensity of the use in the soil, dynamic processes are taking place leading to changes in structure, fertility, acidity and microbiological activity. Microorganisms are the most numerous group of organisms in the overall metabolic activity of the soil and represent good indicators of soil health, as they respond quickly to changes in the soil ecosystem (Milošević, 2008).

The microbial community structure and the enzymatic activity of microorganisms are different in different soil types, and are the result of interactions between the soil type, plant species, localization of the microorganism in rhizosphere, anthropogenization and other factors (Marschner et al., 2001). Owing to the microbiological processes in the soil, the circulation of matter, synthesis and mineralization of humus and nutrition of plants (Jarak et al., 2005) take place so that microbiological and biochemical properties can be used as potential indicators of soil quality (Nannipieri et al., 2003). Microorganisms in their metabolic processes excrete a variety of biotic substances into their environment affecting plants, their growth and development, the process of photosynthesis, resistance to diseases and pests, and therefore, the yield and quality of cultivated plants (Šarčević - Todosijević et al., 2018 ). On the other hand, plants, over root hairs, excrete different substances that stimulate the development and activity of microorganisms.

Soil micro-organisms play an important role in nutrient cycles, including maintaining grassland soil porosity, fertility, degradation of natural organic matter and mineralization of nutrients (van Eekeren et al., 2007; Castro et al., 2010).

The aim of this research was to examine the quality of the soil under natural and sown grasslands in the Kosjeric Municipality area, based on the chemical characteristics and the total number of microorganisms. 


\section{MATERIAL AND METHODS}

Sampling of soil was carried out during the autumn of 2018 on natural and sown grasslands located on the territory of the Municipality of Kosjerić. Eleven samples were taken from sown grasslands and marked with S1 to S11, while 19 were from natural grasslands and had codes $\mathrm{P} 1$ to $\mathrm{P} 19$.

The sampling itself was carried out by a probe at a depth of 0 to $25 \mathrm{~cm}$ in several places on each plot, and the number of individual samples increased if it was noticed that the plot was not homogeneous.

The reason for this sampling is to obtain a more realistic picture of the properties of the tested soil. All individual soil samples taken from one plot were mixed and homogenized and a unique sample of about $1 \mathrm{~kg}$ of weight was taken from the obtained soil mass. The chemical properties of the soil were determined by standard methods in the chemical laboratory of the Institute for Forage Crops Kruševac.

Biological activity of the soil (biogenicity) is monitored on the basis of the total number of microorganisms. The total number of microorganisms was determined on the agarized soil extract by indirect dilution method, by seeding the soil suspension from $10^{-5}$ dilutions. The number of grown colonies is calculated to 1 gram of absolutely dry soil (Jarak and Đurić, 2006).

The results obtained during the research were processed with the statistical program StatSoft STATISTICA 8.0. The significance of the difference between the numbers of microorganisms of the soil from the examined grasslands was determined on the basis of the Fisher LSD test.

\section{RESULTS AND DISCUSSION}

The sampled soils showed different acidity, but the greatest number of soils had acidic and highly acidic chemical reaction (19 samples). Nine soil samples had poorly acidic chemical reaction, and only 2 of the analyzed soils showed a neutral reaction (Tab. 1).

The chemical reaction of the soil is considered one of the most important characteristics of the environment (Pislea and Sala, 2012), and it has a strong influence on the growth of plants, the regime and biological availability of nutrients and the way that the ions from nutrients reach the root of the plant. 
Table 1 The chemical properties and the total number of microorganisms (log of the number) of the studied soils

\begin{tabular}{|c|c|c|c|c|c|c|c|}
\hline \multirow{2}{*}{ Samples } & \multicolumn{2}{|c|}{$\mathrm{pH}$} & \multirow{2}{*}{$\begin{array}{l}\mathrm{N} \\
\%\end{array}$} & \multirow{2}{*}{$\frac{\mathrm{P}_{2} \mathrm{O}_{5}}{\mathrm{mg} / 100 \mathrm{~g}}$} & \multirow{2}{*}{$\frac{\mathrm{K}_{2} \mathrm{O}}{\mathrm{mg} / 100 \mathrm{~g}}$} & \multirow{2}{*}{$\begin{array}{c}\text { Humus } \\
\%\end{array}$} & \multirow{2}{*}{$\begin{array}{l}\text { Total number of } \\
\text { microorganisms }\end{array}$} \\
\hline & $\mathrm{H}_{2} \mathrm{O}$ & $\mathrm{KCl}$ & & & & & \\
\hline $\mathrm{P} 1$ & 5.57 & 4.82 & 0.257 & 4.0 & 7.87 & 3.79 & $6.114^{\text {d.e.f }}$ \\
\hline $\mathrm{P} 2$ & 6.09 & 5.17 & 0.166 & 5,1 & 19.03 & 2.17 & $5.922^{\text {g.h }}$ \\
\hline S1 & 6.75 & 5.99 & 0.223 & 4.1 & 9.33 & 2.66 & $6.301^{\text {a.b.c }}$ \\
\hline P3 & 5.97 & 4.70 & 0.260 & 5.1 & 21.98 & 2.09 & $6.041^{\text {e.f.g }}$ \\
\hline P4 & 5.88 & 4.63 & 0.239 & 5.0 & 17.54 & 2.91 & $5.954^{\mathrm{f..g}}$ \\
\hline P5 & 7.08 & 6.33 & 0.197 & 6.8 & 16.84 & 2.50 & $6.302^{\text {a.b.c }}$ \\
\hline $\mathrm{S} 2$ & 6.28 & 4.87 & 0.219 & 5.1 & 9.19 & 2.92 & $6.204^{\text {b.c.d.e }}$ \\
\hline $\mathrm{S} 3$ & 5.98 & 4.68 & 0.195 & 3.9 & 4.36 & 2.48 & $6.042^{\text {e.f.g }}$ \\
\hline P6 & 5.67 & 4.18 & 0.221 & 3.8 & 3.50 & 3.10 & $6.114^{\text {d.e.f }}$ \\
\hline $\mathrm{S} 4$ & 5.93 & 4.56 & 0.181 & 3.9 & 13.80 & 2,65 & $6.272^{\text {a.b.c.d }}$ \\
\hline P7 & 7.19 & 6.43 & 0.383 & 72.0 & 40.65 & 4,06 & $6.431^{\mathrm{a}}$ \\
\hline P8 & 6.34 & 5.73 & 0.216 & 33.8 & 63.36 & 4.16 & $6.342^{a . b}$ \\
\hline P9 & 6.04 & 4.90 & 0.239 & 5.0 & 13.05 & 3.53 & $6.113^{\text {d.e.f }}$ \\
\hline P10 & 5.75 & 4.17 & 0.096 & 5.1 & 12.43 & 2.68 & $5.903^{\text {g.h }}$ \\
\hline S5 & 5.04 & 3.97 & 0.197 & 8.7 & 7.34 & 2.66 & $5.954^{\text {f.g }}$ \\
\hline P11 & 5.75 & 4.28 & 0.166 & 5.1 & 578 & 2.01 & $5.778^{h}$ \\
\hline P12 & 7.26 & 6.76 & 0.248 & 13.4 & 18.38 & 2.70 & $6.301^{\text {a.b.c }}$ \\
\hline S6 & 6.29 & 4.93 & 0.377 & 5.3 & 10.82 & 3.32 & $5.955^{\text {f.g }}$ \\
\hline P13 & 6.86 & 6.24 & 0.167 & 11.1 & 32.13 & 2.78 & $6.112^{\text {d.e.f }}$ \\
\hline P14 & 6.4 & 4.95 & 0.209 & 5.3 & 9.86 & 3.40 & $6.202^{\text {b.c.d.e }}$ \\
\hline S7 & 6.32 & 5.43 & 0.248 & 5.1 & 19.56 & 3.12 & $6.232^{\text {b.c.d }}$ \\
\hline P15 & 6.42 & 5.70 & 0.225 & 6.0 & 19.51 & 2.82 & $6.145^{\text {c.d.e }}$ \\
\hline P16 & 6.31 & 5.19 & 0.244 & 7.9 & 22.82 & 2.41 & $6.300^{\text {a.b.c }}$ \\
\hline S8 & 6.34 & 5.48 & 0.239 & 8.7 & 19.27 & 2.71 & $6.255^{\text {b.c.d }}$ \\
\hline P17 & 7.21 & 6.43 & 0.179 & 13.6 & 17.49 & 2.75 & $6.285^{\text {a.b.c.d }}$ \\
\hline P18 & 7.48 & 6.61 & 0.183 & 11.1 & 26.95 & 2.35 & $6,174^{\text {b.c.d.e }}$ \\
\hline P19 & 6.91 & 6.43 & 0,181 & 6.8 & 21.00 & 2.48 & $6,279^{\text {a.b.c.d }}$ \\
\hline S9 & 7.45 & 6.37 & 0.195 & 10.8 & 19.36 & 3.34 & $6,230^{\text {b.c.d }}$ \\
\hline S10 & 7.11 & 6.02 & 0.207 & 6.0 & 23.39 & 3.03 & $6,257^{\text {b.c.d }}$ \\
\hline S11 & 6.24 & 5.21 & 0.195 & 6.9 & 34.29 & 3.94 & $6,172^{\text {b.c.d.e }}$ \\
\hline
\end{tabular}

The results of the performed microbiological analyses showed that the number of total microflora ranged from 5.778 to 6.431 ( $\log$ of the number), whereas the highest biogenicity was found in the soil of the natural grassland (P7), which had poorly acidic chemical reactions and was well supplied with nutrients. It was followed by soil samples of similar chemical properties, while soil samples with a lower $\mathrm{pH}$ value had fewer microorganisms (Table 2). In accordance with the results of this study, Baath and Anderson (2003) stated that, with the increase in acidity of the soil, microorganism biomass decreases. Microbiological activity in acidic soils is not high, because aerobes are suppressed, nitrification is poor, nitrogen fixators are poorly distributed, and the rhizosphere is limited to a shallow surface area (Aciego and Brookes, 2008). 
Organic matter is an important and irreplaceable component of every soil. Its role is reflected, above all, in favorable impact on the structure of the soil. The largest number of samples was characterized by the average content of humus and nitrogen, which is favorable from the aspect of the number and activity of the soil microflora.

The number and activity of microorganisms depend on the physical and chemical properties of the soil (Marinkovic et al., 2008), and on the basis of the representation of certain groups of microorganisms, the intensity of humification or dehumification as well as the quality of the humus content can be estimated (Tintor et al., 2007). Milošević et al. (2000) stated that the content of organic matter is a limiting factor for microbial populations, since it represents a source of energy for their metabolism. The content of easily available phosphorus in the grassland soils, covered by our research, was generally low, which is directly related to the acidity of the soil. The application of adequate agro-technical measures (crop rotation, fertilization, processing) creates conditions for maintaining microbial population and increasing the capacity of these microorganisms for the mobilization of phosphorus (Jarak and Čolo, 2007). The sampled soils were relatively well provided by easily soluble potassium, and phosphorus dynamics in soil is closely related to the dynamics of the biological cycle in which microorganisms play a central role (Vassilev et al., 2006). Applying appropriate corrective measures for acidic soil, such as the application of $\mathrm{CaCO}_{3}$, can affect microbiological activity, which also has a favorable effect on fertility of the soil (Milošević et al., 1994).

\section{CONCLUSION}

The results of soil testing under natural and sown grasslands in the Kosjerić Municipality point out to the absence of the application of appropriate agro-technical measures, i.e. the extensive approach as a way of soil management. In order to ensure adequate conditions for the development of the root system of plants and the activity of soil microorganisms, phosphatization and calcification measures should be applied. The application of adequate arrangement measures would allow better use of potential soil for the development of plants and microorganisms.

\section{ACKNOWLEDGMENTS}

Research in this paper is part of the project entitled "Improving the genetic potential and technology of production of fodder in the function of sustainable livestock development", 
TR31057, funded by the Ministry of Education, Science and Technological Development of the Republic of Serbia.

\section{REFERENCES}

Aciego JC, Brookes PC. 2008: Substrate availability and pH as factors controling microbial biomass, activity and community structure in an arable soil. Soil Biology and Biochemistry 51, 569-657.

Arsić S, Jovanović M. 2013: Opportunities for biomass production in meadows and pastures as factor of improving sheep production in Serbia. Agro - knowledge Journal 14 (2): 297-307 (in Serbian with English summary).

Baath E, Anderson TH. 2003: Comparison of soil fungal/bacterial ratios in a $\mathrm{pH}$ gradient using phisiological and PLFA-based tehniques. Soil Biology and Biochemistry 35: 955-963.

Babić S, Lugić Z, Sokolović D, Radović J, Dinić B, Anđelković S, Petrović M. 2016: State and problems in forage produce in Western Serbia. Proceedings of XXI Symposium on biotechnology, 11- 12 March Čačak, 21(23):161-166 (in Serbian with English summary).

Castro FH, Classe TA, Austin EE, Norby JR, Schadt C. 2010: Soil microbial community responses to multiple experimental climate change drivers. Appl Environ Microbiol 2076 (4): 999-1007.

Jarak M, Čolo J. 2007: Microbiology of soil. University of Novi Sad, Faculty of Agriculture, Novi Sad, 209 p (in Serbian).

Jarak M, Đurić S. 2006: Microbiology practicum. University of Novi Sad, Faculty of Agriculture, Novi Sad, 146 p (in Serbian).

Jarak M, Milošević N, Milić V, Mrkovački N, Đurić S, Marinković J. 2005: Microbiological activities: fertility and soil degradation indicators. Economics of Agriculture, 52(4): 483-493 (in Serbian with English summary).

Marinković J, Milošević N, Tintor B, Sekulić P, Nešić Lj. 2008: Microbial properties of fluvisol at different locations in the vicinity of Novi Sad. Field and Vegetable Crops Research Novi Sad 45 (2): 215-223 (in Serbian with English summary).

Marschner P, Yang C.H, Lieberei R, Crowley DE. 2001: Soil and plant specific effect on bacterial community composition in the rhizosfere, Soil biology and Biochemistry 33: 1437-1445. 
Milošević N. 2008: Microorganisms: Bioindicators of soil health/quality. Field and Vegetable Crops Research Novi Sad 45 (1), 205-215 (in Serbian with English summary).

Milošević N, Govedarica M, Jarak M. 2000: Microbiological properties of the soil at the RimskiŠančevi experiment field. Field and Vegetable Crops Research Novi Sad 33, 13-20. (in Serbian with English summary).

Milošević N, Govedarica M, Jarak M, Hadžić V, Sekulić P. 1994: Correlation between enzyme activities and meliorative practices applied to solonetz soil. Soil and Plant, 43(1): 25-37.

Nannipieri P, Ascher J, Ceccherini M.T, Landi L, Pietramellara G, Renella G. 2003: Microbial diversity and soil functions, Eur J Soil Sci. 54: 665-670.

Pislea D, Sala F. 2012: The influence of mineral fertilization on the distribution of nutrients in the soil. Bulletin UASVM, Agriculture 69(1): 225-231.

Simić A, Vučković S, Tomić, Bijelić Z, Mandić V, Krga I. 2015: Management of permanent grasslands in Serbia: Evaluation of current fertilizer practice. Proceedings of the $4^{\text {th }}$ International Congress "New perspectives and challenges of sustainable livestock production", 7-9 October, 2015, Belgrade: 381-393.

Šarčević - Todosijević, Lj, Živanović, Lj, Petrović B, Marinković T, Popović V. 2018: The number and significance of actinomycetes in the soil in the stage of physiological corn (Zea mays L.) kernel maturity. Proceedings of XXIII Symposium on biotechnology, 9- 10 March, Čačak: 82-88 (in Serbian with English summary).

Tintor B, Milošević N, Vasin J. 2009: Microbiological properties of chernozem of southern Bačka according to different methods of land use. Field and Vegetable Crops Research Novi Sad 46 (1): 189-198 (in Serbian with English summary).

vanEekeren N, Murray PJ, Smeding FW. 2007: Soil biota in grassland, its ecosystem services and the impact of management permanent and temporary grassland. Grassland Science in Europe 12: 247-257.

Vassilev N, Vassileva M, Nikolaeva I. 2006: Simultaneous P-solubilizing and biocontrol activity of microorganisms: potentials and future trends. Applied Microbiology and Biotechnology 71: 137-144. 


\section{Examination of soils under grasslands in the territory of Kosjeric municipality}

Snežana Anđelković*, Snežana Babić, Tanja Vasić, Jasmina Milenković, Jordan Marković, Mladen Prijović, Đorđe Lazarević

Institute for Forage Crops, Globoder 37251 Kruševac, Serbia

*Correspondiing author: Snežana Anđelković, snezana.andjelkovic@ikbks.com

\section{IZVOD}

Za uspešnu biljnu proizvodnju potrebno je obezbediti optimalne uslove za mikrobiološke procese, pošto mikroorganizmi imaju značajnu ulogu u održavanju plodnosti zemljišta. Oni brzo reaguju na promene u zemljišnom ekosistemu, tako da predstavljaju dobre indikatore zdravlja zemljišta. U cilju unapređenja biljne proizvodnje i pravilnog korišćenja zemljišta ispitivan je kvalitet zemljišta pod prirodnim i sejanim travnjacima na području Opštine Kosjerić. Analizirano je jedanaest uzoraka sa sejanih i devetnaest uzoraka zemljišta sa prirodnioh travnjaka, pri čemu su odredjena hemijska svojstva i ukupni broj mikroorganizama. Većina uzoraka zemljišta je kisele hemijske reakcije, sa srednjim sadržajem humusa i azota, niskim sadržajem fosfora i dovoljnim količinama kalijuma. Brojnost ukupne mikroflore kretala u rasponu od 5.778 do 6.431 (log broja) po gramu apsolutno suvog zemljišta.

Ključne reči: zemljište, travnjaci, mikroorganizmi 